\title{
PENAMPILAN PRODUKSI KELINCI JANTAN PADA PEMBERIAN SILASE PAKAN BLOCK \\ (The Performance Of Rabbits In Feeding Block Silage)
}

\author{
Andiani Listyowati, $\mathbf{A}^{1)}$ dan Haryanto, $\mathbf{H}^{1)}$ \\ ${ }^{1)}$ Staf Pengajar Sekolah Tinggi Penyuluhan Pertanian Magelang \\ Jl. Magelang-Kopeng KM 7 Purwosari Tegalrejo Magelang 56192 \\ email: andangandi@yahoo.com
}

Diterima: 3 Mei 2015 Disetujui: 25 Juni 2015

\begin{abstract}
The research aimed to know the performance of rabbit bucks in feeding block silage. The material used in this research consisted of 20 local male rabbits period 4 months old, storied individual battery system cages made of wood 20 units each cage was equipped with a feed and drinking water. Feed ingredients were consisted of grass, bran, corn flour, pollard, palm cake, fish meal, soybean meal, premix, molasse, EM4 and casava flour. Tools used included electric scales, blockfeeder and oven.

Rabbits were placed randomly in storied individual cages. The data that observed were feed consumption, body weight rabbits, daily body weight gain $(\mathrm{PBBH})$ and feed conversion. This research was carried out experimentally, using a completely randomized design, with four kinds of feeding treatment and each treatment consisted of 5 replicates ie $P 1=$ complete feed without fermentation, $P 2=$ complete feed without fermentation, formed block, P3 = fermented complete feed and P4 = fermented complete feed, formed block

Variables that measured were average feed consumption per head, daily body weight gain, feed conversion. To determine the effect of treatment on the observed variables used Analysis Of Variance (ANOVA) in one direction (One way).If there was a difference between the four treatment then continued with analysis of Duncan's multiple range test.

The research resulted in final body weight of rabbits aged 5 weeks in treatment $P 1$, P2, P3 and P4 showed no difference, namely in sequence of $1562.600 \mathrm{~g} ; 1478.832 \mathrm{~g}$; $1788.520 \mathrm{~g}$; and $1572.800 \mathrm{~g}$. Daily body weight gain (PBBH) in this research were not differ and respectively $11.777 \mathrm{~g} ; 12.458 \mathrm{~g} ; 16,981 \mathrm{~g}$ and $16.617 \mathrm{~g}$. Feed treatment affected on dry matter intake $(P<0.05)$. The average consumption of BK treatment P3 (120.615 g / head / day) did not differ with BK consumption P1 (119.187 g / head / day) and both were higher than the average consumption P2 BK treatment $(80.187 \mathrm{~g} /$ head / day) and P4 (70.552 g/ head / day), and the second (P2 and P4) showed no difference. Treatment of feeding affected on feed conversion $(P<0.05)$. The average value of feed conversion obtained in treatment P1 (2,789) was different and higher than feed conversion in treatment P2 (1,965) and P4 (1.586), but not unlike the treatment P3 (2.406). While feed conversion in P2 treatment was not different than feed conversion in treatment P3, and also did not differ by treatment with P4. Feed conversion was at the lowest P4 treatment and smaller than feed conversion in treatment P1 and P3, but no different fromfeed conversion of $P 2$ treatment.

The conclusion from this research was feeding blocksilage affected on consumption and feed conversion of male rabbits $(P<0.05)$. Feeding block resultedlower consumption
\end{abstract}


and feed conversion than feeding mash $(P<0.05)$. Feeding block silage gave better efficiency of feed using to produce body weight of male rabbit.

Keywords: performance, rabbit, blockfeed silage

\begin{abstract}
ABSTRAK
Penelitian bertujuan untuk mengetahui penampilan produksi kelinci jantan pada pemberian silase pakan block.Materi yang digunakan dalam penelitian ini terdiri atas 20 ekor kelinci lokal jantan periode lepas sapih umur 4 bulan, kandangbertingkatsistembaterai individual yang terbuat dari kayu sebanyak 20 unit masing-masing kandang dilengkapi dengan tempat pakan dan air minum. Bahan pakan terdiri dari rumput, bekatul, jagung giling, pollard, bungkil sawit, tepung ikan, bungkil kedele, premix, tetes, EM4 dantepungtapioka. Peralatan yang digunakanmeliputi:timbangan listrik, alatpencetakpakan block dan oven.

Kelinci ditempatkan secara acak pada kandang individu bertingkat. Data yang diamati meliputi konsumsi pakan, bobot badan kelinci, pertambahan bobot badanharian $(\mathrm{PBBH})$ dan konversi pakan. Penelitian ini dilakukan secara eksperimen, menggunakan Rancangan Acak Lengkap, dengan perlakuan 4 macam pemberian pakandan tiap-tiap perlakuan terdiri dari 5 ulanganyaitu $\mathrm{P} 1=$ Pakan komplit tanpafermentasi, $\mathrm{P} 2=$ Pakankomplit tanpa fermentasi, dibentuk block, P3 = Pakan komplit difermentasi dan P4 = Pakan komplit difermentasi, dibentuk block.

Peubah yang diamati Konsumsi Pakan Rata-rata per Ekor, Pertambahan Bobot Badan Harian, Konversi Pakan. Untuk mengetahui pengaruh perlakuan terhadap peubah yang diamati digunakan Analisis Of Variance (ANOVA) satuarah (One way). Apabilaterdapat perbedaan antara keempat perlakuan tersebut maka dilanjutkan dengan analisis Uji Wilayah GandaDuncan.

Penelitian menghasilkan bobot badan akhir kelinci umur 5 minggu pada perlakuan P1, P2, P3 dan P4 tidak menunjukkan perbedaan, yaitu secara berurutan sebesar 1562,600 g; 1478,832 g; 1788,520 g; dan 1572,800 g.Pertambahan bobot badan harian (PBBH) pada penelitian ini tidak berbeda dan secara berurutan adalah 11,777 g; 12,458 g; 16, $981 \mathrm{~g}$ dan 16,617 g. Perlakuan pakan berpengaruh terhadap konsumsi bahan kering $(\mathrm{P}<0,05)$. Rataan konsumsi BK perlakuan P3 (120,615g/ekor/hari) tidak berbeda dengan konsumsi BK P1 (119,187g/ekor/hari) dan keduanya lebih tinggi dibandingkan rataan konsumsi BK perlakuan P2 (80,187 g/ekor/hari) maupun P4 (70,552g/ekor/hari), serta keduanya (P2 dan P4) tidak menunjukkan perbedaan. Perlakuan pemberian pakan berpengaruh terhadap konversi pakan $(\mathrm{P}<0,05)$. Rata-rata nilai konversi pakan yang diperoleh pada perlakuan $\mathrm{P} 1$ $(2,789)$ berbeda dan lebih tinggi dibandingkan konversi pakan pada perlakuan P2 $(1,965)$ dan P4 (1,586), namun tidak berbeda dengan perlakuan P3 $(2,406)$. Sementara konversi pakan pada perlakuan P2 tidak berbeda dengan konversi pakan pada perlakuan P3, dan juga tidak berbeda dengan perlakuan P4.Konversi pakan pada perlakuan P4 paling rendah dan lebih kecil dibandingkan konversi pakan pada perlakuan P1 dan P3, namun tidak berbeda dengan konversi pakan perlakuan P2.

Kesimpulan dari penelitian ini adalah bahwa pemberian silase pakan block berpengaruh terhadap konsumsi dan konversi pakan kelinci jantan $(\mathrm{P}<0,05)$. Pemberian pakan block menghasilkan konsumsi dan konversi pakan yang lebih rendah dibandingkan pemberian pakan mash $(\mathrm{P}<0,05)$.Pemberian silase pakan block memberikan efisiensi penggunaan pakan yang lebih baik.
\end{abstract}

Kata kunci: Penampilan produksi, Kelinci, Silase Pakan Block 
PENDAHULUAN

\section{Latar Belakang}

Upaya mendukung pemenuhan protein hewani dan swasembada daging, satudiantara ternak yang mempunyai potensi cukup tinggi sebagai penghasil daging adalah ternak kelinci. Sujatman, D. (2012) melaporkan bahwa ternak kelinci memiliki potensi yang sangat besar untuk dikembangkan dalam rangka mencapai swasembada daging. Potensi tersebut terkait dengan keunggulan yang dimiliki kelinci, yaitu: (1) Beternak kelinci tidak memerlukan modal dan biaya pemeliharaan yang tinggi, bahkan dapat diusahakan dalam skala rumah tangga; (2) Kelinci mempunyai kemampuan reproduksi yang tinggi; dan (3) Daging kelinci memiliki rasa dan gizi yang lebih unggul dibandingkan ternak lain.Kebutuhan modal yang relatif kecil, jenis pakan yang mudah dan perkembangbiakan yang cepat menjadikan kelinci sangat relevan dan cocok sebagai alternatif usaha bagi petani miskin yang tidak memiliki lahan luas dan tidak mampu memelihara ternak besar (Sitorus et al., 1982).

Pakan merupakan salah satu faktor penentu keberhasilan usaha pemeliharaan ternak disamping faktor pemilihan bibit dan tata laksana pemeliharaan yang baik. Untuk dapat menghasilkan kelinci dengan produksi yang tinggi, diperlukanpemeliharaan secara intensif dengan pemberian pakan yang memenuhi syarat, baik secara kualitas maupun kuantitas.

Pengawetan pakan bertujuan agar pakan dapat tersedia secara kontinu dan bertahan (awet) untuk jangka waktu yang cukup lama. Teknologi fermentasi anaerob diharapkan dapat digunakan dalam pengawetan pakan komplit seperti dilaporkan dari hasil penelitian Rizqiani, A. (2011) bahwa performa kelinci jantan lokal peranakan New Zealand White yang diberi silase ransumkomplit mempunyai kualitas performa yang sama dengan kelinci yang diberi pelet ransumkomplit. Sementara pelet ransum komplit tidak dapat disimpan dalam waktu lama. Oleh karena itu, penggunaan teknologi fermentasi anaerob berupa silase ransum komplit sangat diperlukan. Pembuatan silase ransum komplit menjadi bentuk block bertujuan untuk menjaga nilai kualitas nutrisi maupun ketahanan daya simpannya.Hasil penelitian Sobri, M. (2010) menjelaskan bahwa biskuit kelinci disamping mudah dalam aplikasinya juga digunakan untuk menjaga mutu, baik kualitas kesetabilan nutriennya maupun ketahanan daya simpannya. Pelet khusus untuk kelinci sangat penting, karena kualitas yang lebih homogen dan tetap sehingga peternak bisa menyimpan pakan untuk jangka waktu yang lama (Manshur, 2009). Hasil penelitian Nugroho, S.S dkk. (2012) menunjukkan bahwa kelinci lebih menyukai konsentat dalam bentuk pelet daripada mash. Pertumbuhan kelinci yang diberi konsentrat dalam bentuk pelet lebih baik daripada yang diberi pakan mash.

Berdasarkan uraian tersebut diatas, maka penelitian yang dilaksanakan berjudul Pemberian Silase Pakan Block Terhadap Penampilan Produksi Kelinci Jantan.

\section{Tujuan Penelitian}

Tujuan dari penelitian ini adalah untuk mengetahui penampilan produksi kelinci jantan pada pemberian silase pakan block. 
MATERI DAN METODE

\section{Materi}

Bahan yang digunakan dalam penelitian ini terdiri atas: 20 ekor kelinci lokal jantan periode lepas sapih umur 4 bulan, kandang bertingkat sistem baterai individual yang terbuat dari kayu sebanyak 20 unit yang dilengkapi dengan tempat pakan dan airminum. Bahan pakan terdiri dari rumput, bekatul, jagung giling, pollard, bungkil sawit, tepung ikan, bungkil kedele, mineral, tetes, EM4 dan tepung tapioka. Peralatan yang digunakan meliputi: timbangan digital, drum plastik, panci pengukus, nampan plastik,alat pencetak pakan block.

\section{Metode}

\section{Pembuatan Pakan}

Bahan-bahan pakan semua dalam kondisi kering dan halus, selanjutnya ditimbang sesuai komposisi dan dicampur secara homogen. Separuh bagian campuran pakan difermentasikan dan separuh lainnya tidak difermentasikan. Pembuatan silase atau fermentasi pakan dilakukan dengan cara difermentasikan secara anaerob dalamdrum plastik selama 3 minggu.

Pembuatan pakan block dengan cara, campuran pakan yang telah homogen dikukus selama 30 menit. Setelah dikukus dicetak menggunakan mesin pencetak dan dikeringkan menggunakan oven listrik dengan suhu $55^{\circ} \mathrm{C}$ hingga kering. Demikian pula pembuatan silase pakan block dengan cara pakan yang telah difermentasi, dikukus dan dibuat bentuk block dengan cara yang sama.
Pakan dari masing-masing perlakuan penelitian diuji kandungan nutrisinya menggunakan analisis proksimat.

\section{Feeding trial}

Sebelum penelitian dimulai, dilakukan adaptasi pakan terhadap kelincikelinci agar terbiasa dengan pakan sesuai perlakuan penelitian. Adaptasi dilakukan selama 7 hari. Kelinci ditempatkan secara acak pada kandang individu bertingkat. Penelitian terdiri dari 4 perlakuan, dan tiaptiap perlakuan terdiri dari 5 ulangan, sehingga terdapat 20 satuan percobaan.

Pakan dan air minum diberikansecara ad libitum. Pemberian pakan dilakukan dua kali sehari, pada pagi hari pukul 07.00 08.00 WIB dan pada sore hari pada pukul $16.00-17.00$ WIB.

\section{Pengambilan data}

Data yang diamati meliputi konsumsi pakan, bobot badan kelinci, pertambahan bobot badan harian $(\mathrm{PBBH})$ dan konversi pakan.

Konsumsi pakan adalah jumlah pakan yang dikonsumsi setiap hari dan diperoleh dengan menghitung selisih antara jumlah pemberian dan sisa pakan. Konsumsi bahan kering (BK) pakan adalah jumlah bahan kering pakan yang dikonsumsi ternak setiap hari, dihitung berdasarkan konsumsi pakan dan kandungan BK pakan.

Pertambahan bobot badan harian kelinci (PBBH) dihitung dengan cara mengurangi bobot badan akhir dengan bobot badan awal dibagi lama pemeliharaan. Konversi pakan dihitung dengan cara membagi konsumsi pakan ratarata perekor perhari dengan pertambahan bobot badan harian 


\section{Rancangan Percobaan}

Penelitian dilakukan secara eksperimen, menggunakan Rancangan Acak Lengkap, dengan perlakuan 4 macam pemberian pakan, yaitu:

P1 = Pakan komplit tanpa fermentasi

P2 = Pakan komplit tanpa fermentasi, dibentuk block

P3 = Pakan komplit difermentasi

P4 = Pakan komplit difermentasi, dibentuk block

Model linier yang digunakan dalam penelitian ini adalah:

$$
Y_{i j}=\mu+\tau_{i}+\varepsilon_{i j}
$$

Keterangan:

$\mathrm{Y}_{\mathrm{ij}}=$ Nilai pengamatan dari perlakuan kei ulangan ke-j

$\mu=$ Nilai tengah umum dari seluruh pengamatan

$\tau_{\mathrm{i}}=$ Pengaruh perlakuan ke-i

$\varepsilon_{\mathrm{ik}}=$ Pengaruh percobaan dari perlakuan ke-i dan ulangan ke-j

$\mathrm{i}=1,2,3,4$ (perlakuan)

$\mathrm{j}=1,2,3,4,5$ (ulangan)

\section{Peubah yang Diamati}

Peubah yang diamati pada penelitian ini meliputi:

a. Bobot badan akhir kelinci umur 5 minggu

b. Konsumsi pakan rata-rata perekor perhari

c. Pertambahan bobot badan harian

d. Konversi pakan

\section{Analisis Data}

Untuk mengetahui pengaruh perlakuan terhadap peubah yang diamati digunakan Analisis of Variance (ANOVA) satu arah (One way). Apabila terdapat perbedaan antara keempatperlakuan maka dilanjutkan dengan analisis Uji Wilayah Ganda Duncan.

\section{HASIL DAN PEMBAHASAN}

Hasil penelitian pemberian silase pakan block terhadap penampilan produksi kelinci jantan disajikan pada tabel rataan bobot badan akhir kelinci umur 5 minggu, pertambahan bobot badan harian (PBBH), konsumsi bahan kering (BK) dan konversi pakan pada perlakuan yang berbeda (Tabel $1)$.

Tabel 1. Rata-rata Nilai Peubah pada Perlakuan yang Berbeda

\begin{tabular}{lrrrr}
\hline \multirow{2}{*}{ Peubah } & \multicolumn{4}{c}{ Perlakuan } \\
\cline { 2 - 5 } & \multicolumn{1}{c}{ P1 } & \multicolumn{1}{c}{ P2 } & \multicolumn{1}{c}{ P3 } & P4 \\
\hline Bobot Badan Akhir (g/ekor) & 1562,600 & 1478,832 & 1788,520 & 1572,800 \\
PBBH (g/ekor/hari) & 11,777 & 12,458 & 16,981 & 16,617 \\
Konsumsi BK (g/ekor/hari) & $119,187^{\mathrm{a}}$ & $80,187^{\mathrm{b}}$ & $120,615^{\mathrm{a}}$ & $70,552^{\mathrm{b}}$ \\
Konversi Pakan & $2,789^{\mathrm{a}}$ & \multicolumn{1}{c}{$1,965^{\mathrm{bc}}$} & $2,406^{\mathrm{ab}}$ & $1,586^{\mathrm{c}}$ \\
\hline a, b, c Superskrip yang berbeda pada baris yang sama menunjukkan perbedaan pada \\
P<0,05
\end{tabular}




\section{Bobot Badan Akhir}

Berdasarkan Tabel 2 diketahui bobot badan akhir kelinci umur 5 minggu pada perlakuan P1, P2, P3 dan P4 tidak menunjukkan perbedaan, yaitu secara berurutan sebesar 1562,600 g; 1478,832 g; $1788,520 \mathrm{~g}$; dan1572,800 g.Bobot badan akhir yang diperoleh dipengaruhi oleh pertumbuhan danjumlah pakan yang dikonsumsi serta nutrien yang dapat diserap tubuh kelinci, makin banyak nutrien yang diserap tubuh akan menghasilkan bobot badan akhir yang lebih tinggi. Hal ini menunjukkan bahwa pemberian pakan komplit yang difermentasi maupun tidak difermenasi, yang dibuat bentuk block ataupun bentuk mash tidak berpengaruh terhadap bobot badan akhir kelinci umur 5 minggu.

\section{Pertambahan Bobot Badan Harian (PBBH)}

Pertambahan bobot badan harian (PBBH) pada penelitian ini tidak berbeda atau dengan kata lain pemberian pakan pada perlakuan yang berbeda tidak berpengaruh terhadap PBBH kelinci. PBBH yang diperoleh pada perlakuan P1, P2, P3 dan P4 secara berurutan adalah 11,777 g; 12,458 g; 16, 981 g dan 16,617 g. Salah satu faktor yang mempengaruhi pertambahan bobot badan adalah konsumsi pakan. Konsumsi dan kecernaan pakan yang tinggi akan menghasilkan pertambahan bobot badan yang tinggi (Rasyid, 2009). Hasil yang diperoleh pada penelitian ini tidak jauh berbeda dengan hasil penelitian Kurniawati (2001) yaitu sebesar $12,780 \pm 2,741$ g/ekor/hari demikian pula hasil penelitian Rizqiani, A. (2011) menunjukkan bahwa pertambahan bobot badan kelinci yang diberi pakan pelet komplit sebesar17,60 $\pm 10,92 \mathrm{~g} /$ ekor/hari tidak berbeda dibandingkan pertambahan bobot badan kelinci yang diberi pakan silase komplit yaitu sebesar 17,29 $\pm 15,30$ g/ekor/hari.

Penelitian Cheeke (1987) dalam Rizqiani, A. (2011) melaporkan bahwa pertumbuhan kelinci di daerah tropis sebesar 10 - 20 gram per hari. Dengan demikian maka pertambahan bobot badan kelinci pada penelitian ini sudah sesuai dan kandungan nutrien pakan penelitian dapat memberikan pengaruh yang baik terhadap pertambahan bobot badan kelinci.

\section{Konsumsi Bahan Kering (BK)}

Berdasarkan Tabel 2 diatas dapat ditunjukkan bahwa perlakuan pakan berpengaruh terhadap konsumsi bahan kering $(\mathrm{P}<0,05)$. Rata-rata konsumsi $\mathrm{BK}$ pakan bentuk mash yang dibuat silase P3 (120,615g/ekor/hari) tidak berbeda dengan konsumsi BK pakan bentuk mash yang tidak dibuat silase P1 (119,187g/ekor/hari) dan keduanya lebih tinggi dibandingkan rataan konsumsi BK pakan bentuk block yang tidak dibuat silase P2 $(80,187$ g/ekor/hari) maupun pakan bentuk block yang dibuat silase P4 (70,552g/ekor/hari), serta keduanya (P2 dan P4) tidak menunjukkan perbedaan. Jumlah pakan yang diberikan harus memenuhi jumlah yang dibutuhkan oleh kelinci sesuai dengan tingkat umur atau bobot badan kelinci. Menurut Irlbeck (2001) dalam Rizqiani, A. (2011), kelinci akan mengkonsumsi pakan sekitar 5\% dari bobot badannya, dengan demikian konsumsi bahan kering pada perlakuan $\mathrm{P} 1, \mathrm{P} 2$, dan $\mathrm{P} 3$ telah memenuhi kebutuhan bahan kering untuk kelinci.Sementara menurut NRC (1977), kebutuhan bahan kering kelinci muda bobot badan (BB) 1,8-3,2 kg, kebutuhan bahan 
kering sebanyak 5,4-6,2\% (BB).

Konsumsi pakan bentuk block baik yang difermentasi (P4) maupun tidak difermentasi (P2) lebih rendah $(\mathrm{P}<0,05)$ dibandingkan konsumsi pakan bentuk mash baik yang mengalami proses fermentasi (P3) maupun yang tidak mengalami fermentasi (P1). Namun pertambahan bobot badan dan bobot badan akhir yang diperoleh dari semua perlakuan tidak menunjukkan perbedaan. Hal ini mengindikasikan bahwa perlakuan $\mathrm{P} 2$ dan P4 lebih efisien dan efektif dalam menghasilkan pertumbuhan kelinci dibandingkan perlakuan P1 dan P3. Kondisi ini berhubungan dengan retention time (lama waktu pakan menempati saluran pencernaan).Pakan bentuk block akan lebih lama berada dalam saluran pencernaan karena dibutuhkan waktu lebih lama untuk memecah pakan bentuk block tersebut, sedangkan pakan bentuk mash (P1 dan P3) waktu yang diperlukan untuk mengecilkan partikel pakan cenderung lebih singkat.Menurut Nugroho, dkk. (2012), pakan yang lebih lama berjalan di dalam saluran pencernaan akan mengalami penyerapan nutrien yang lebih baik daripada pakan yang sebentar melewati saluran pencernaan, khususnya pada usus halus tempat terjadinya penyerapan sari-sari makanan.Penyerapan sari-sari makanan terjadi pada villi yang terdapat pada dinding usus. Makanan yang lebih lama berada dalam usus akan lebih lama bersinggungan dengan villi usus, akibatnya nutrien yang bisa dicerna menjadi lebih banyak daripada makanan yang sebentar berada dalam usus halus.Dengan demikian walaupun konsumsi pakan bentuk block lebih rendah daripada bentuk mash, namun nutrien yang dapat dicerna dan diserap oleh villi usus lebih banyak sehingga dapat menghasilkan pertambahan bobot badan dan bobot badan akhir yang tidak berbeda diantara semua perlakuan.

\section{Konversi Pakan}

Konversi pakan merupakan salah satu indikator untuk menilai tingkat efisiensi penggunaan pakan.Nilai konversi pakan rendah menunjukkan efisiensi penggunaan pakan baik, sebaliknya nilai konversi pakan tinggi menunjukkan efisiensi penggunaan pakan rendah.Konversi pakan kelinci sangat dipengaruhi oleh konsumsi pakan dan pertambahan bobot badan kelinci.Perlakuan pemberian pakan berpengaruh terhadap konversi pakan $(\mathrm{P}<0,05)$. Rata-rata nilai konversi pakan yang diperoleh pada perlakuan P1 $(2,789)$ berbeda dan lebih tinggi $(\mathrm{P}<0,05)$ dibandingkan konversi pakan pada perlakuan P2 $(1,965)$ dan P4 (1,586), namun tidak berbeda dengan perlakuan P3 $(2,406)$.Sementara konversi pakan pada perlakuan P2 tidak berbeda dengan konversi pakan pada perlakuan P3, dan juga tidak berbeda dengan perlakuan P4.Konversi pakan pada perlakuan P4 paling rendah dan lebih kecil dibandingkan konversi pakan pada perlakuan P1 dan P3, namun tidak berbeda dengan konversi pakan perlakuan P2(Tabel 2). Faktor yang mempengaruhi konversi pakan diantaranya adalah kualitas pakan, keturunan dan manajemen pemberian pakan (Anggorodi, 1985).

Konversi pakan pada perlakuan pemberian pakan bentuk block baik yang difermentasi maupun tidak difermentasi lebih rendah dibandingkan konversi pakan bentuk mash, hal ini berarti pemberian pakan bentuk block lebih efisien. Hasil penelitian ini tidak berbeda dengan hasil penelitian Nugroho dkk. (2012) yang menyatakan konversi pakan kelinci yang diberi konsentrat dalam bentuk pelet lebih 
rendah $(\mathrm{P}<0,05)$ daripada yang diberi konsentrat dalam bentuk mash. Dengan demikian pakan bentuk pelet ataupun bentuk block lebih efisien untuk meningkatkan bobot badan kelinci daripada konsentrat dalam bentuk mash.

Berdasarkan hasil yang diperoleh menunjukkan bahwa konversi pakan dengan perlakuan pakan komplit yang difermentasi dan dibuat menjadi bentuk block menghasilkan tingkat efisiensi penggunaan pakan yang paling baik. Pakan yang mengalami proses fermentasi akan terjadi pemecahan komponen-komponen kompleks menjadi komponen yang lebih sederhana pada komposisi kimia dari nutrisi dalam pakan. Kandungan asam amino, karbohidrat, lemak, vitamin dan mineral, protein dan serat kasar, $\mathrm{pH}$ dan aroma akan mengalami perubahan akibat aktivitas dan perkembangbiakan mikroorganisme selama fermentasi (Sajimin, 2011). Demikian pula dengan bentuk block akan disukai kelinci dan mempunyai masa simpan yang lebih lama.Menurut hasil penelitian Sobri, M. (2010) menggunakan biskuit kelinci (bici) mempunyai keunggulan yaitu kandungan gizi dan protein yang tinggi, mempercepat pertumbuhan, menekan angka kematian dan mempercepat reproduksi dan jumlah anak dalam satu kelahiran (litter size). Selain itu mudah digunakan, dagingnya menjadi lebih empuk, berserat halus dan aman terhadap lingkungan karena kotoran kelinci tidak berbau, juga bisa sebagai solusi untuk mengatasi kesulitan mendapatkan rumput bagi peternak kelinci hias yang bermukim di perkotaan.

\section{KESIMPULAN DAN SARAN}

\section{Kesimpulan}

Pemberian silase pakan block berpengaruh terhadap konsumsi dan konversi pakan kelinci jantan $(\mathrm{P}<0,05)$.Pemberian pakan block menghasilkan konsumsi dan konversi pakan yang lebih rendah dibandingkan pemberian pakan mash $(\mathrm{P}<0,05)$.Pemberian silase pakan block memberikan efisiensi penggunaan pakan yang lebih baik.

\section{Saran}

Diperlukan penelitian lanjutan pada penggunaan pakan silase block pada ternak kelinci betina untuk tujuan pembibitan dan penggunaan bahan pakan lokal.

\section{DAFTAR PUSTAKA}

Anggorodi, R. 1985. Ilmu Makanan Ternak Umum. Jakarta: PT. Garuda Pustaka Utama.

Kurniawati, N. 2001. "Penggemukan kelinci muda untuk produksi fryer dengan kepadatan kandang yang berbeda." Skripsi. Bogor: Fakultas Peternakan. Institut Pertanian Bogor.

Manshur, F. 2009. Kelinci: Pemeliharaan secara Ilmiah, Tepat dan Terpadu. Nuansa cendekia. Bandung.

National Reseach Council. 1977. Nutrient Requirement of Rabbit. Washington: National Academic of Science.

Nugroho, S. S., S. P. Sasmito Budhi, dan Panjono. 2012. "Pengaruh Penggunaan Konsentrat dalam Bentuk Pelet dan Mash pada Pakan 
Dasar Rumput Lapangan terhadap Palatabilitas dan Kinerja Produksi Kelinci Jantan.” Buletin Peternakan Vol. 36 (3): 169-173, Oktober 2012. Yogyakarta: Fakultas Peternakan, Universitas Gadjah Mada.

Rasyid, H. 2009. "Performa Produksi Kelinci Local Jantan pada Pemberian Rumput Lapang dan Berbagai Level Ampas Tahu." Skripsi. Bogor: Fakultas Peternakan. Institut Pertanian Bogor.

Rizqiani, A. 2011. "Performa Kelinci Potong Jantan Lokal Peranakan New Zealand White yang Diberi Pakan Silase atau Pelet Ransum, Komplit.” Skripsi. Departemen Ilmu Nutrisi dan Teknologi Pakan, Fakultas Peternakan, Institut Pertanian Bogor. http://Dosen.Narotama.Ac.Id/WpContent/Uploads/2012/03/PerformaKelinci-Potong-Jantan-LokalPeranakan-New-Zealand-WhiteYang-Diberi-Pakan-Silase-AtauPelet-Ransum-Komplit.pdf. Diakses pada 4 Juni 2014

Sajimin. 2011. "Medicago sativa L. (Alfalfa) sebagai tanaman pakan ternak harapan di Indonesia." Wartazoa. Vol.21 No.2: 91-98.

Sitorus P., S. Sastrodihardjo, Y. C. Raharjo, I. G. Putu, Santoso, B. Sudaryanto dan A. Nurhadi. 1982. "Budidaya Peternakan Kelinci di Jawa." Laporan. Bogor: Pusat Penelitian dan Pengembagan Peternakan.

Sobri, M. 2010. Dosen UMM Temukan "Biskuit untuk Kelinci": Formula Pakan Kelinci tanpa Rumput. http://www.umm.ac.id/id/beritailmiah-umm-2-dosen-umm- temukan-biskuit-untuk-kelinciformula-pakan-kelinci-tanparumput.html. Diakses pada 20 Juni 2014

Sujatman, D. 2012. Pengembangan Ternak Kelinci dalam Rangka Mendukung Swasembada Daging Tahun 2014 (Studi Kasus di Kecamatan Cireunghas Kabupaten Sukabumi). Berbagi Ilmu Penyuluhan Pertanian Ternak Kelinci. 